\title{
The Effectiveness of Zeolite Enriched with Amino Acids in the Cultivation of Crops in the Middle Volga Region (on the Example of Millet)
}

\author{
Alevtina Kulikova*, Evgeniy Yashin, Alexander Karpov and Alexander Romashkin \\ Ulyanovsk State Agrarian University named after P.A. Stolypin, Ulyanovsk, Russia
}

\begin{abstract}
The paper presents the results of studies on the effectiveness of zeolite, including enriched with amino acids, in the cultivation of millet. The study was carried out on the experimental field of Ulyanovsk State Agrarian University in 2019 by the following scheme: 1. Control, 2. Zeolite $500 \mathrm{~kg} / \mathrm{ha}$, 3. Zeolite enriched with amino acids, $500 \mathrm{~kg} / \mathrm{ha}$. In 2020 , the following options were introduced into the experimental scheme. Control, 2. Zeolite $250 \mathrm{~kg} / \mathrm{ha}, 3$. Zeolite $500 \mathrm{~kg} / \mathrm{ha}$, 4. Zeolite enriched with amino acids, $250 \mathrm{~kg} / \mathrm{ha}$ 5. Zeolite enriched with amino acids, $500 \mathrm{~kg} / \mathrm{ha}$. The soil was typical medium loamy chernozem. Zeolite and zeolite fertilizers have a positive effect on the agrophysical, water-physical and agrochemical properties of the soil. The content of agronomically valuable aggregates in the arable layer increased by 5.7 and $11.5 \%$, respectively; the reserves of productive moisture by $9-11 \mathrm{~mm}$, the amount of mineral nitrogen by 0.5 and $6.5 \mathrm{mg} / \mathrm{kg}$, available phosphorus increased by 9 and $16 \mathrm{mg} / \mathrm{kg}$, potassium - per 6 and $8 \mathrm{mg} / \mathrm{kg}$ of soil. The use of zeolite enriched with amino acids in a dose of $500 \mathrm{mg} / \mathrm{kg}$ increased the grain yield by more than one ton per hectare with a significant increase in environmental safety. For the cultivation of millet, it is most feasible to use zeolite enriched with amino acids in a dose of $250 \mathrm{~kg} / \mathrm{ha}$.
\end{abstract}

\section{Introduction}

Millet (Panicum milacumt) is one of the most important cereal crops in terms of taste and nutritional qualities, slightly inferior to rice, buckwheat, oats, etc.

In addition, the crop is most adapted to arid conditions, being one of the most drought-resistant and heat-resistant crops, it suffers less from pests and diseases. It is not surprising that the areas of this crop are expanding both in the world and in Russia (392.7 thousand hectares in 2019).

The potential yield of millet is high and amounts to $4.5 \mathrm{t} / \mathrm{ha}$, while the real productivity of grain, in particular in Ulyanovsk region, does not exceed 1.5 t/ha. A scientifically grounded fertilization system plays an important role. In the initial period of development, millet plants need nitrogen, in the phase of stalking and panicle formation, they need nitrogen, potassium and other elements, and during the grain filling, they need phosphorus. Therefore, it is very important to provide plants with all elements during the entire growing season.

In addition, millet is one of the most silicon-loving crops. Numerous studies have proven that silicon is an integral factor in crop productivity that prevents the soil from degradation [1-6]. Despite the fact that the content of silicon in soils is $30-35 \%$, its deficit is growing. Therefore, in order to maintain an optimal level of silicon nutrition, scientists and agricultural practitioners suggest introducing silicon-containing materials into the fertilization system of agricultural crops. Natural siliceous rocks such as diatomites, zeolites, bentonites, etc. are promising [7-9]. Due to their unique physicochemical properties and crystalline structure, it is possible to use these rocks not only as a silicon fertilizer, but also to produce complex organomineral fertilizers.

In 2019, together with BioResurs LLC (Ulyanovsk), the authors developed a new zeolite fertilizer and enriched it animal amino acids. BioResource LLC produced the first experimental samples. The research aim is to study the effectiveness of zeolite, including those enriched with amino acids, in the system of fertilizing agricultural crops. This paper presents the results obtained in the cultivation of millet.

\section{Materials and methods}

1. Natural zeolite of the Yushansk deposit of Ulyanovsk region with the following chemical composition: $\mathrm{SiO}_{2 \text { total. }} 56.6 \%$; SiO2amorph. $26.7 \%$; $\mathrm{CaO}-13.3 \%$; $\mathrm{K}_{2} \mathrm{O}-1.25 \% ; \mathrm{MgO}-1.73 \% ; \mathrm{P}_{2} \mathrm{O}_{5}-0.49 \% ; \mathrm{SO}_{3}-$ $0.5 \%$. The total ion exchange capacity is $93 \mathrm{mg}$-eq $/ 100 \mathrm{~g}$. The main role in the exchange belongs to calcium (86-88\%). The water retention capacity reaches $96.13 \%$.

2. Zeolite enriched with amino acids, which contain $(\%)$ : aspartic acid $(3.31+0.11)$, glutamic acid $(2.88+$ $0.43)$, serine $(0.70+0.11)$, histidine $(0.52+0.08)$, glycine $(0.95+0.14)$, threonine $(0.60+0.09)$, arginine

Corresponding author: volkova-ivinaelena@yandex.ru 
$(0.89+0.13)$, alanine $(1.30+0.19)$, tyrosine $(1.15+$ $0.17)$, cystine $(0.32+0.05)$, valine $(1.82+0.27)$, methionine $(0.42+0.06)$, phenylalanine $(1.76+0.26)$, isoleucine $(3.18+0.48)$, leucine $(4.46+0.67)$, lysine $(7.41+1.11)$, proline $(3.10+0,46)$.

3 . The soil is typical chernozem with the following content in the arable layer $(0-30 \mathrm{~cm})$ : humus $4.7 \%$, mobile (available) phosphorus and potassium 155 and $106 \mathrm{mg} / \mathrm{kg}$ of soil. The reaction of the soil solution is 6.7 units of $\mathrm{pHKCl}$.

4. The experimental crop is millet Saratovskoe 12, which has excellent technological and biochemical properties: uniformity, coarse-grained and spherical grain, increased yield of coarse millet fraction (75-78\%), resistance to melanosis, high content of carotenoid pigments, high consumer advantages of cereals (yellowness and vitreousness of the kernel).

In 2019, the experiment scheme consisted of 3 options: 1. Control, 2. Zeolite $500 \mathrm{~kg} / \mathrm{ha}, 3$. Zeolite enriched with amino acids, $500 \mathrm{~kg} / \mathrm{ha}$. In 2020, variants were introduced into the experimental scheme with the introduction of experimental fertilizers into the soil at $250 \mathrm{~kg} / \mathrm{ha}: 1$. Control, 2. Zeolite $250 \mathrm{~kg} / \mathrm{ha}, 3$. Zeolite $500 \mathrm{~kg} / \mathrm{ha}$, 4. Zeolite enriched with amino acids, $250 \mathrm{~kg} / \mathrm{ha}$ 5 . Zeolite enriched with amino acids, $500 \mathrm{~kg} / \mathrm{ha}$.

Zeolite was enriched with amino acids and tested by BioResource LLC (Ulyanovsk).

\section{Results and discussion}

Any crop imposes requirements on the physical properties of the soil, which determine the water and thermal regimes of soils, intensity of microbiological, biochemical, physicochemical processes and soil fertility. Table 1 shows the indicators of the physical state of typical chernozem, which indicate their significant changes when introducing zeolite and zeolite fertilizers.

The data show that when zeolite and zeolite fertilizers are introduced into the soil, there is a significant improvement in the physical state of the soil: due to an increase in the structural coefficient from 1.77 to 2.11 and 3.10 units, the content of agronomically valuable aggregates increased by 3.7 and $11.4 \%$ when using pure zeolite and 5.7 and $11.5 \%$ when using zeolite enriched with amino acids. The latter is due to the ability of polysilicic acids to glue soil particles into aggregates [10]. The improvement in the structural condition was accompanied by the optimization of soil density.

In the arid conditions of the Middle Volga region, the regulation of the water regime of the soil is one of the main problems, since its moisture supply is in the first minimum, which sharply limits the production process of plants. Under these conditions, along with agrotechnical conditions aimed at the accumulation, conservation and economical use of soil moisture, the role of natural sorbents increases. They are able to absorb, retain and gradually (economically) consume it. Zeolites have a high water-holding capacity, which reaches $96 \%$. The above is confirmed by the data in Figure 1 .
Table 1. The influence of zeolite, including enriched with amino acids, on the structural state and density of the arable layer of chernozem typical for millet crops

\begin{tabular}{|c|c|c|c|c|c|}
\hline \multirow[t]{2}{*}{ Option } & \multicolumn{3}{|c|}{$\begin{array}{c}\text { Content of } \\
\text { aggregates, \% } \\
\text { (dry sieving) } \\
\end{array}$} & \multirow{2}{*}{$\begin{array}{c}\text { Cs } \\
\text { (coefficient } \\
\text { of } \\
\text { structure) }\end{array}$} & \multirow[t]{2}{*}{$\begin{array}{c}\text { Density, } \\
\text { g/cm }^{3}\end{array}$} \\
\hline & 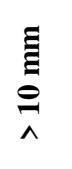 & 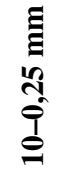 & 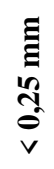 & & \\
\hline Control & 26.4 & 64.2 & 9.4 & 1.77 & 1.26 \\
\hline Zeolite, $250 \mathrm{~kg} / \mathrm{ha}$ & 23.8 & 67.9 & 8.3 & 2.11 & 1.18 \\
\hline Zeolite, $500 \mathrm{~kg} / \mathrm{ha}$ & 19.3 & 75.6 & 5.1 & 3.10 & 1.10 \\
\hline $\begin{array}{c}\text { Zeolite enriched } \\
\text { with amino acids, } \\
250 \mathrm{~kg} / \mathrm{ha}\end{array}$ & 29.1 & 69.9 & 1.0 & 2.33 & 1.14 \\
\hline $\begin{array}{c}\text { Zeolite enriched } \\
\text { with amino acids, } \\
500 \mathrm{~kg} / \mathrm{ha}\end{array}$ & 18.7 & 75.7 & 5.5 & 3.13 & 1.08 \\
\hline $\mathrm{LSD}_{05}$ & 1.5 & 3.1 & 0.3 & 0.2 & 0.02 \\
\hline
\end{tabular}

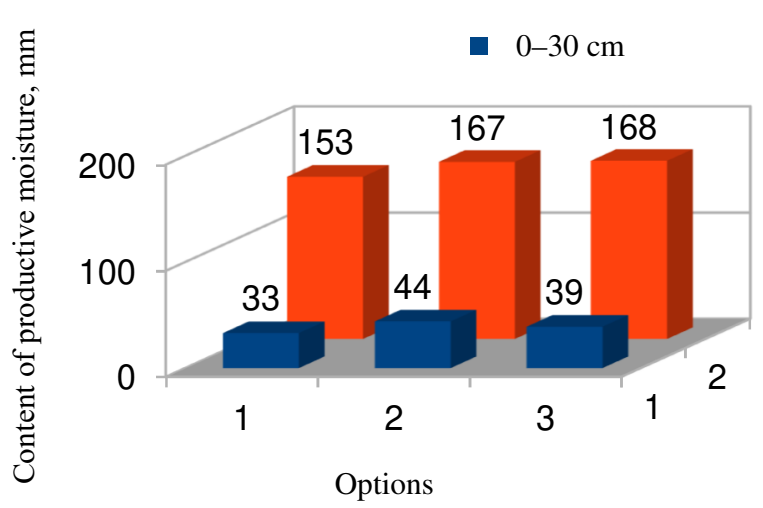

Fig. 1. Content of productive moisture in tne soil, $\mathrm{mm}$

The results of the experiments showed that the winter-spring moisture reserves in the forest-steppe of the Volga region are quite sufficient to obtain normal seedlings of spring crops: $30-35 \mathrm{~mm}$ in the arable layer and $150 \mathrm{~mm}$ in the meter layer. However, it is very important to preserve this moisture and use it economically during the growing season. In this regard, the introduction of zeolite both in pure form and enriched with amino acids, contributed to the maintenance of productive moisture reserves during the entire growing season: by $9-11 \mathrm{~mm}$ in the arable layer and by $14-15 \mathrm{~mm}$ in the meter layers. The latter is due to the crystal structure of zeolite (porosity, adsorption capacity, etc.), and properties of amorphous silica. Matychenkov [6] showed that one silicon atom can hold up to 119 water molecules; Ayler [11] showed that one mole of $\mathrm{SiO}_{2}$ contains up to 330 moles of $\mathrm{H}_{2} \mathrm{O}$.

The improvement of the physical and water-physical properties of soils was accompanied by an increase in the activity of microorganisms and effective fertility of the soil (Table 2).

The tables show the advantage of the options with both zeolite and zeolite fertilization in improving the nutritional regime of typical chernozem. Despite the increased consumption of nutrients, their content by the end of the growing season exceeded the control option: 
mineral nitrogen $\left(\mathrm{NO}_{3}+\mathrm{NH}_{4}\right)$ by $0.5-6.5 \mathrm{mg} / \mathrm{kg}, \mathrm{P}_{2} \mathrm{O}_{5}-$ by $9-16 \mathrm{mg} / \mathrm{kg}, \mathrm{K}_{2} \mathrm{O}-$ by $6-8 \mathrm{mg} / \mathrm{kg}$.

Table 2. The influence of zeolite and zeolite fertilizers on the agrochemical parameters of the arable soil layer under millet crops

\begin{tabular}{|c|c|c|c|c|c|}
\hline Option & $\mathbf{N H}_{\left.\mathbf{4}+\mathbf{N O}_{3}\right)}$ & $\mathbf{P}_{\mathbf{2}} \mathbf{O}_{\mathbf{5}}$ & $\mathbf{K}_{\mathbf{2}} \mathbf{O}$ & $\mathbf{S i O}_{\mathbf{2}}$ & $\mathbf{p H} \mathbf{K C}$ \\
\hline Control & 18.7 & 143 & 102 & 28.0 & 6.4 \\
\hline $\begin{array}{c}\text { Zeolite, } \\
500 \mathrm{~kg} / \mathrm{ha}\end{array}$ & 19.2 & 152 & 110 & 34.6 & 6.7 \\
\hline $\begin{array}{c}\text { Zeolite enriched } \\
\text { with amino } \\
\text { acids, 500 kg/ha }\end{array}$ & 25.2 & 159 & 108 & 38.9 & 6.8 \\
\hline LSD05 & 1.1 & 5 & 4 & 2.3 & 0.3 \\
\hline
\end{tabular}

Particular attention should be paid to the change in the reaction of the soil solution, which, when using zeolite (including those enriched with amino acids), decreased by $0.3-0.4 \mathrm{pHKCl}$ units. The latter indicates the neutralizing ability of zeolite, due to the high content of calcium and magnesium in the zeolite of the Yushansk deposit (up to $17 \%$ or more).

When zeolite was introduced into the soil, the content of available silicon increased by 6.6 and $10.9 \mathrm{mg} / \mathrm{kg}$. Millet is one of the most silicon-loving crops. There is a direct relationship between the content of monosilicic acid in the soil and yield which can be described by the equation:

where $\mathrm{y}$ - grain yield, $\mathrm{t} / \mathrm{ha}$;

$$
\mathrm{y}=0,11 \mathrm{x}-0,58,
$$

$\mathrm{x}$ - content of water-soluble silicon, $\mathrm{mg} / \mathrm{kg}$.

The regression equation is (Fig. 2).

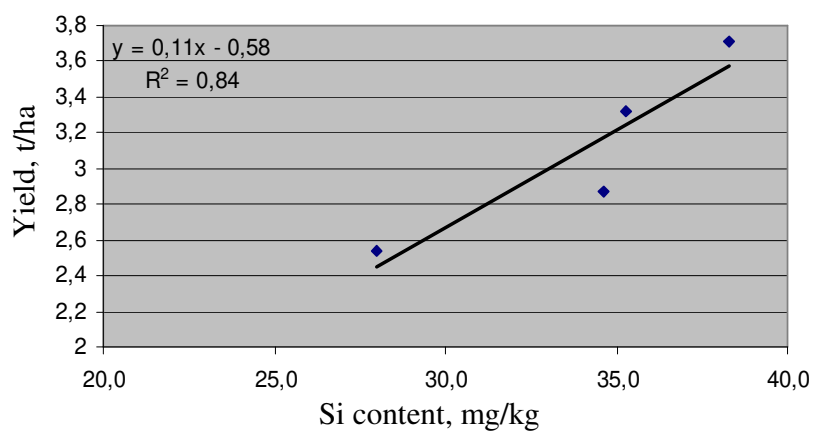

Fig. 2. Dependence of the yield of millet (y) on the content of typical water-soluble silicon (x) in chernozem

Fertilizers are one of the main factors in the formation of high yields, primarily through the impact on the soil environment. Siliceous rocks (including zeolite) improve the basic physical properties of soil and conditions for plant nutrition. As Table 2 shows, zeolites and zeolite fertilization can improve plant nutrition with all basic elements (nitrogen, phosphorus, potassium and silicon) and preserve soil moisture. Improvement of the plant habitat inceases the crop yield (Tables 3 and 4).

The first tests of zeolite and zeolite fertilizers revealed their very high efficiency: an increase in the grain yield when using zeolite enriched with amino acids was $1.17 \mathrm{t} / \mathrm{ha}$, or $46 \%$. In 2020 , the results of the previous studies were confirmed. Moreover, the 2020 experiments showed that to obtain the same yield, a dose of $250 \mathrm{~kg} / \mathrm{ha}$ of zeolite enriched with amino acids is sufficient.

Table 3. The influence of zeolite and zeolite fertilizers on the yield of millet (2019)

\begin{tabular}{|c|c|c|c|}
\hline Option & \multirow{2}{*}{$\begin{array}{c}\text { Productivity, } \\
\text { t/ha }\end{array}$} & \multicolumn{2}{|c|}{ Deviation, $\mathbf{\pm}$} \\
\cline { 3 - 4 } & 2.54 & t/ha & \% \\
\hline Control & 2.87 & +0.33 & - \\
\hline Zeolite, $500 \mathrm{~kg} / \mathrm{ha}$ & 3.71 & +1.17 & +46 \\
\hline $\begin{array}{c}\text { Zeolite enriched with } \\
\text { amino acids, } 500 \mathrm{~kg} / \mathrm{ha}\end{array}$ & & & \\
\hline LSD $_{05}$ & 0.17 & & \\
\hline
\end{tabular}

Table 4. The influence of zeolite and zeolite fertilizers on the yield of millet (2020)

\begin{tabular}{|c|c|c|c|}
\hline \multirow[t]{2}{*}{ Option } & \multirow{2}{*}{$\begin{array}{c}\text { Productivity, } \\
\text { t/ha }\end{array}$} & \multicolumn{2}{|c|}{ Deviation, \pm} \\
\hline & & t/ha & $\%$ \\
\hline Control & 2.33 & - & - \\
\hline Zeolite, $250 \mathrm{~kg} / \mathrm{ha}$ & 2.55 & +0.22 & +9 \\
\hline Zeolite, $500 \mathrm{~kg} / \mathrm{ha}$ & 2.72 & +0.39 & +17 \\
\hline $\begin{array}{c}\text { Zeolite enriched with } \\
\text { amino acids, } 250 \mathrm{~kg} / \mathrm{ha}\end{array}$ & 3.08 & +0.75 & +32 \\
\hline $\begin{array}{l}\text { Zeolite enriched with } \\
\text { amino acids, } 500 \mathrm{~kg} / \mathrm{ha}\end{array}$ & 3.17 & +0.84 & +36 \\
\hline LSD $_{05}$ & 0.18 & & \\
\hline
\end{tabular}

An analysis of the research results confirmed that the most significant agrochemical indicators in the cultivation of millet on typical chernozem are the content of mineral nitrogen and water-soluble silicon. The corresponding dependences are described by the equations

$$
\begin{aligned}
& y=0,15 x_{1}-0,23\left(R^{2}=0,94\right), \\
& y=0,11 x_{2}-0,58\left(R^{2}=0,84\right),
\end{aligned}
$$

where $\mathrm{y}-$ millet grain yield, $\mathrm{t} / \mathrm{ha}$;

$\mathrm{x}_{1}-$ mineral nitrogen content, $\mathrm{mg} / \mathrm{kg}$;

$\mathrm{x}_{2}-$ content of water-soluble silicon, $\mathrm{mg} / \mathrm{kg}$.

The higher yield of millet was due to zeolite enriched with amino acids introduced into the soil; the content of mineral nitrogen increased by $6.5 \mathrm{mg} / \mathrm{kg}(35 \%)$, silicon - by $16 \mathrm{mg} / \mathrm{kg}(37 \%)$...

Plant products are the basis of the national food security, especially in the context of economic sanctions. Both the volume of products and their its quality determine the health of the nation. Therefore, with a high technogenic load on the environment, it is important to prevent the ingress of toxicants into products. In terms of the environmentally safe agricultural production, the greatest danger is posed by pesticides and heavy metals, the most dangerous of which are cadmium, lead, nickel. Heavy metals also include elements that are absolutely necessary for plants; when they are excessively supplied to the plant, they have a highly toxic effect (zinc and copper, which are part of a number of enzymes that regulate vital processes in the body). On the other hand, they are highly toxic. Thus, the lethal dose of zinc for humans is $200 \mathrm{mg} / \mathrm{kg}$ of body weight.

As can be seen from Table 5, the use of zeolite, including those enriched with amino acids, can significantly reduce the intake of metals in products: the accumulation of lead and cadmium in grain decreased by two or more times. 
Table 5. Content of heavy metals in millet grain

\begin{tabular}{|c|c|c|c|c|c|}
\hline Option & $\mathbf{Z n}$ & $\mathbf{C u}$ & $\mathbf{P b}$ & $\mathbf{C d}$ & $\mathbf{N i}$ \\
\hline Control & 12,1 & 5,1 & 0,22 & 0,012 & 1,19 \\
\hline Zeolite, 500 kg/ha & 11,4 & 4,3 & 0,12 & 0,005 & 1,11 \\
\hline $\begin{array}{c}\text { Zeolite enriched with } \\
\text { amino acids, 500 kg/ha }\end{array}$ & 11,1 & 4,4 & 0,11 & 0,005 & 1,12 \\
\hline LSD05 & 0,4 & 0,2 & 0,04 & 0,002 & 0,02 \\
\hline MPC in products & 50 & 30 & 0,5 & 0,10 & 5,0 \\
\hline
\end{tabular}

Evaluation of the economic efficiency of production is also important.
The main economic indicators of millet cultivation, depending on the use of new zeolite prolonged-release fertilizers are presented in Table 6.

An analysis of the economic efficiency of millet cultivation using experimental fertilizers confirmed the established patterns for other crops: the highest profitability of millet grain production was shown by the option with the use of zeolite enriched with amino acids in a dose of $250 \mathrm{~kg} / \mathrm{ha}$ with a profitability level of $97 \%$ (control $78 \%$ ).

Table 6. The economic efficiency of millet cultivation

\begin{tabular}{|c|c|c|c|c|c|c|}
\hline Options & $\begin{array}{c}\text { Yield, } \\
\text { t/ha }\end{array}$ & $\begin{array}{c}\text { Cost from 1 ha, } \\
\text { RUB. }\end{array}$ & $\begin{array}{c}\text { Production } \\
\text { costs, RUB }\end{array}$ & \multicolumn{2}{c|}{$\begin{array}{c}\text { Cost of 1 } \\
\text { ton, rub. }\end{array}$} & \multicolumn{2}{c|}{$\begin{array}{c}\text { Conditional net } \\
\text { income, rubles }\end{array}$} & $\begin{array}{c}\text { Profitability, } \\
\text { \% }\end{array}$ \\
\hline Control & 2,33 & 25630 & 14362 & 6164 & 11268 & 78 \\
\hline Zeolite, 250 kg/ha & 2,55 & 28050 & 16108 & 6317 & 11941 & 74 \\
\hline Zeolite, 500 kg/ha & 2,72 & 29920 & 18685 & 6869 & 11235 & 60 \\
\hline $\begin{array}{c}\text { Zeolite enriched with } \\
\text { amino acids, 250 kg/ha }\end{array}$ & 3,08 & 33880 & 17199 & 5584 & 16681 & 97 \\
\hline $\begin{array}{c}\text { Zeolite enriched with } \\
\text { amino acids, 500 kg/ha }\end{array}$ & 3,17 & 34870 & 20618 & 6504 & 14252 & 6 \\
\hline
\end{tabular}

The use of zeolite enriched with amino acids decreased the production cost of 1 ton of grain to 5584 rubles, while in the control option it was 6164 rubles/ton. Increasing doses of fertilizers increased the cost of production due to the high purchase and application costs.

The highest profit was observed for the option with zeolite enriched with amino acids into the soil in a dose of $250 \mathrm{~kg} / \mathrm{ha}$ (16681 rubles per 1 hectare).

\section{Conclusion}

1. Zeolite and zeolite fertilizers had a positive effect on the structural state of soil: the content of agronomically valuable aggregates increased by 5.7 and $11.5 \%$, respectively.

2. The introduction of zeolite into the soil, both in pure form and enriched with amino acids, contributed to the maintenance of productive moisture reserves at a higher level during the entire growing season: by $9-11 \mathrm{~mm}$ in the arable layer and by $14-15 \mathrm{~mm}$ in meter soil layers.

3. Improvement of the agrophysical and waterphysical properties of the soil was accompanied by an improvement in its nutritional regime: despite the increased nutrition of plants, the amount of mineral nitrogen in the arable layer increased by 0.5 and $6.5 \mathrm{mg} / \mathrm{kg}$, phosphorus - by 9 and $16 \mathrm{mg} / \mathrm{kg}$, potassium - by 6 and $8 \mathrm{mg} / \mathrm{kg}$.

4. The use of zeolite enriched with amino acids in a dose of $500 \mathrm{~kg} / \mathrm{ha}$ in 2019 increased the grain yield by more than 1 ton per 1 hectare. The dose of $250 \mathrm{mg} / \mathrm{kg}$ (2020) was not worse than the dose of $500 \mathrm{~kg} / \mathrm{ha}$.

5. Zeolite and zeolite fertilizers contributed to the production of environmentally friendly products: when applied in a dose of $500 \mathrm{~kg} / \mathrm{ha}$, the content of lead and cadmium decreased 2 or more times.

6. The use of zeolite enriched with amino acids is most expedient in a dose of $250 \mathrm{~kg} / \mathrm{ha}$.

\section{Acknowledgments}

The study was funded by the Russian Foundation for Basic Research and Ulyanovsk region within the scientific project No. 19-416-730002.

\section{References}

1. B.P. Loboda, Application of zeolite-containing mineral raw materials in crop production, Agrochim., 6, 78-91 (2000)

2. R.R. Belanger, "The role silicon in plant-pathogen interaction: toward universal model", III Silicon in Agricult. Conf. (Fed. Univ. of Umberland, Umberland, 2005), pp. 34-40

3. A.C. Heather, C.P. Carole, Silica in plants: biological, biochemical and chemical studies, Annals of Botany, 100(7), 1383-1389 (2007).

4. V.V. Matychenkov, The role of mobile silicon compounds in plants and the soil-plant system, Doct. dissertation (Pushchino, 2008), 313 p.

5. E. Epstein, Silicon: its manifold roles in plants, Annals of Appl. Biol., 155, 155-160 (2009)

6. X. Wang, C. Ou-yang, Z. Fan, Effects of exogenous silicon on seed germination and antioxidant enzyme activities of Monordiacharantia under salt stress, J. of Animal \& Plant Sci., 6, 700-708 (2010)

7. O.Kh. Kulikova, Silicon and high-siliceous rocks in the fertilization system of agricultural crops (Ulyanovsk, 2013), 176 p.

8. A.Kh. Kulikova, E.A. Yashin, M.S. Cherkasov, The effectiveness of zeolite, including modified, as a fertilizer for corn, Bull. of the Ulyanovsk State Agricult. Acad., 3(51), 76-84 (2020) 
9. N.E. Samsonova, Silicon in plant and animal organisms, Agrochem., 1, 86-96 (2019)

10. L.D. Norton, Mineralogy of high calcium/sulfurcontaining coal combustion by-products and their effect on soil surface sealing, Agriculture Utilization of Urban and Industrial By-products, Proc. Symp.
Sponsored by Division S-6 and S-7 of the Science Soc. Am. And A-5 the Am. Soc. Agron In Cincinnati., (7-12 Number) (Ohio, 1993)

11. R.K. Ayler, Chemistry of Silica (Mir, Moscow, 1982) 